\title{
Representation and estimation of the power coefficient in wind energy conversion systems
}

\author{
José Genaro González-Hernández ${ }^{1}$ \\ Rubén Salas-Cabrera²
}

Fecha de recepción: 11 de octubre de 2018

Fecha de aprobación: 6 de diciembre de 2018

\begin{abstract}
This paper aims at summarizing various methods used for representing and estimating the power coefficient in wind turbines, such as exponential, sinusoidal and polynomial models, as well as mathematical tools known as state observers. We present an exhaustive bibliographic review of the models used to calculate the power coefficient, given that this type of studies are scarce nowadays. In addition, we propose models that can be satisfactorily used for various analyzes of wind energy conversion systems, such as the representation by a polynomial function of fourth degree and the models based on the stochastic probability function. The relevance of this work is supported by the advantages and disadvantages of the various models and estimators of the power coefficient, which are presented at the end of the article in a comparative table with the purpose of offering to the reader a general summary. Ultimately, this review aims at helping researchers, students, university professors and those who wish to venture into this field, even though they do not have much experience, to establish a quick synthesized understanding of the different models and representations of the power coefficient.
\end{abstract}

Keywords: energy conversion; energy efficiency; power coefficient; state estimation; wind energy.

\section{Representación y estimación del coeficiente de potencia en sistemas de conversión de energía eólica}

\section{Resumen}

Este artículo presenta un resumen de diversos métodos utilizados para la representación y estimación del coeficiente de potencia en aerogeneradores, tales como modelos exponenciales, sinusoidales y polinomiales, así como también de herramientas matemáticas conocidas como observadores de estado. Dada la escasez de estudios que le presenten al lector un panorama general de los modelos utilizados para el cálculo del coeficiente de potencia, este resumen, producto de una revisión bibliográfica exhaustiva, constituye un aporte importante. Otra contribución que se logró fue presentar propuestas propias de modelos que pueden ser utilizados satisfactoriamente para diversos análisis de sistemas de conversión de energía eólica, tales como la representación por una función polinomial de cuarto grado y los modelos basados en la función de probabilidad estocástica. La relevancia de este trabajo se apoya en las ventajas y desventajas de los diversos modelos y estimadores del coeficiente de potencia, las cuales se presentan al final del artículo en una tabla comparativa, con el

\footnotetext{
${ }^{1}$ Ph. D. Instituto Tecnológico de Ciudad Madero (Tamaulipas, México). igenaro.gonzalez@itcm.edu.mx. ORCID: $0000-$ 0002-2126-2304.

${ }^{2}$ Ph. D. Instituto Tecnológico de Ciudad Madero (Tamaulipas, México). ruben.salas@itcm.edu.mx.

Revista Facultad de Ingeniería (Rev. Fac. Ing.) Vol. 28 (50), pp. 77-90. Enero-Marzo, 2019. Tunja-Boyacá, Colombia. L-ISSN: 0121-1129, e-ISSN: 2357-5328, DOI:
} 
propósito de ofrecer al lector un resumen general que le permita una comprensión rápida y sintetizada de los diversos modelos y representaciones del coeficiente de potencia, lo que ayuda a investigadores, estudiantes, profesores universitarios y a quienes deseen incursionar en este campo, aunque no tengan mucha experiencia.

Palabras clave: coeficiente de potencia; conversión de energía; eficiencia energética; energía eólica; estimación de estado.

\section{Representação e estimação do coeficiente de potência em sistemas de conversão de energia eólica}

\section{Resumo}

Este artigo apresenta um resumo de diversos métodos utilizados para a representação e estimação do coeficiente de potência em aerogeradores, tais como modelos exponenciais, sinusoidais e polinomiais, assim como também de ferramentas matemáticas conhecidas como observadores de estado. Dada a escassez de estudos que apresentem ao leitor um panorama geral dos modelos utilizados para o cálculo do coeficiente de potência, este resumo, produto de uma revisão bibliográfica exaustiva, constitui um aporte importante. Outra contribuição que se logrou foi apresentar propostas próprias de modelos que possam ser utilizados satisfatoriamente para diversas análises de sistemas de conversão de energia eólica, tais como a representação por uma função polinomial de quarto grau e os modelos baseados na função de probabilidade estocástica. A relevância deste trabalho apoia-se nas vantagens e desvantagens dos diversos modelos e estimadores do coeficiente de potência, as quais se apresentam no final do artigo em uma tabela comparativa, com o propósito de oferecer ao leitor um resumo geral que lhe permita uma compreensão rápida e sintetizada dos diversos modelos e representações do coeficiente de potência, o que ajuda a pesquisadores, estudantes, professores universitários e aos que desejem incursionar neste campo, ainda que não tenham muita experiência.

Palavras chave: coeficiente de potência; conversão de energia; eficiência energética; energia eólica; estimação de estado.

\section{Para citar este artículo:}

J. G. González-Hernández, and R. Salas-Cabrera, "Representation and estimation of the power coefficient in wind energy conversion systems," Revista Facultad de Ingeniería, vol. 28 (50), pp. 77-90, Ene. 2019. DOI: https://doi.org/10.19053/01211129.v28.n50.2019.8816.

Esta obra está bajo licencia internacional Creative Commons Reconocimiento 4.0

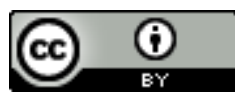




\section{Introduction}

Energy efficiency has always been important in the modern world, especially nowadays given that non-renewable resources are in decline, and in many countries around the world, energy hopes are based on renewable resources such as solar, wind, thermal, oceanic and biomass, which are increasingly exploited using new and modern technologies [1-6].

In the case of wind industry, its growth in recent years has been so great that by the end of 2017 it reached a total installed capacity of 539,123 GW, according to the Global Wind Energy Council (GWEC) [7]; countries such as China, USA, Germany, India, Spain, United Kingdom, France, Canada and Brazil have increased considerably their installed capacity in the last years. Wind farms are being built both on shore and off shore, so the growing and importance of wind energy now and in the future is undeniable.

In Wind Energy Conversion Systems (WECS), the power coefficient is an element of great importance; its understanding, representation and estimation have been thoroughly investigated over the years due to the impact on the exploitable wind energy. Even in the early 1920's, Betz established a limit for power coefficient (Cp) known as Betz limit, which has been subject of analysis ever since [8-12]; moreover, important advances in wind energy technologies have been made in recent years, and several research dealing with emerging technologies have already been published [13].

The power of the wind affects the blades of a wind turbine, but not all the power can be extracted. There are many factors to be considered in order to establish an adequate treatment for analyzing this phenomenon. By definition, the power coefficient in a wind energy conversion system is the fraction of the wind energy that is extracted by the turbine. Therefore, it is very important to analyze the behavior of the power coefficient, given that this is a topic where energetic efficiency is being managed.

The study of $\mathrm{Cp}$ allows finding the point to maximize wind power extraction according to the speed of the wind. Once the value of tip speed ratio that maximizes $\mathrm{Cp}$ is determined, the speed of the generator's rotor can be set by an appropriate control system that allows to obtain the maximum possible $\mathrm{Cp}$ for a certain wind speed; however, this is not the goal of this work.

Many equations have been developed to represent $\mathrm{Cp}$, as well as some observers to estimate its behavior depending on the tip speed ratio, but all of them are just approximations of the real shape of $\mathrm{Cp}$. Cp is not easy to be determined and it changes over time due to real conditions of the system, such as mechanical wear, heating and atmospheric conditions, hence the importance to develop models to represent or to estimate Cp.

Previous studies have reviewed the estimation of wind speed based control on wind turbines, based on polynomial estimation, neural network estimation and nonlinear estimations with Newton Raphson [65]. Other studies have presented an overview of general aspects related to WECS as an introduction that provides general information to the readers [14], and of exponential, sinusoidal and 
algebraic representations for power coefficient [17, 20, 43, 44], failing to include estimators by state observers and own proposals for modeling $\mathrm{Cp}$.

Consequently, and given the scarcity of studies, the context of this investigation turns around the importance to present an overview of representations and estimators of $\mathrm{Cp}$ to provide the reader a summary material of this remarkable topic. We hypothesize that a paper that exhaustively reviews the literature on the representations and estimators of the $\mathrm{Cp}$ in wind turbines will allow researchers, students and even non-experts in the field of wind energy to understand the behavior of the $\mathrm{Cp}$ in wind energy conversion systems, saving time and supporting their investigations.

Here, we summarize the results of most studies related to representations of $\mathrm{Cp}$, such as sinusoidal, exponential and algebraic models; however, these representations only have an acceptable behavior in a certain zone of tip speed radio. On the other hand, there are few estimators of state observers; these models are more complex but better to show the behavior of $\mathrm{Cp}$. After the introduction, we present general aspects such as the definition of $\mathrm{Cp}$ and Betz limit, followed by the exponential, sinusoidal and polynomial representations of Cp according to many authors, and the observers and alternative models for $\mathrm{Cp}$. Subsequently, we describe the results and discuss them, and compare the advantages and disadvantages of $\mathrm{Cp}$ representations. Finally, we present conclusions and references.

\section{Methods}

This section presents general aspects of power coefficient such as its definition and characteristic equation. It also shows representations and estimators of $\mathrm{Cp}$, and alternative models based on the stochastic function of probability.

\section{A. General aspects of power coefficient (Cp)}

When studying a wind turbine, a typical model considers the system like an ideal, conic and closed tube, which means flow is the same along the tube (Fig. 1), so flow conservation law is applied $[15,16](1)$.

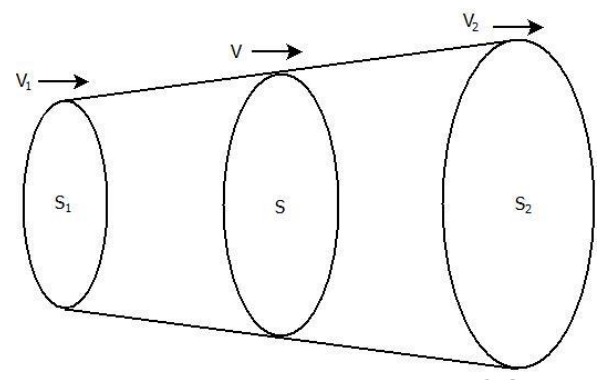

Fig. 1. Ideal disc in WECS.

$$
S_{1} V_{1}=S V=S_{2} V_{2}
$$

Where $S_{1}, S$ and $S_{2}$ represent cross-sectional area upstream, in wind turbine and downstream, respectively. $V_{1}, V$ and $V_{2}$ represent wind before, on, and after the turbine, respectively. By definition, the power coefficient in a wind turbine is given by equation (2). 


$$
C_{p}=\frac{P}{P_{1}}(2)
$$

where $P$ is the power of the wind and $P_{1}$ the power extracted by the turbine. Betz demonstrated in 1919 that the maximum value of $\mathrm{Cp}$ to be obtained is 0.593; nevertheless, some results that apparently have over exceed Betz limits have been reported [8, 9]. Expression (2) may be expressed as equation (3).

$$
C_{p}\left(V_{q}\right)=\frac{1}{2}\left[1-V_{q}^{2}+V_{q}-V_{q}^{3}\right]
$$

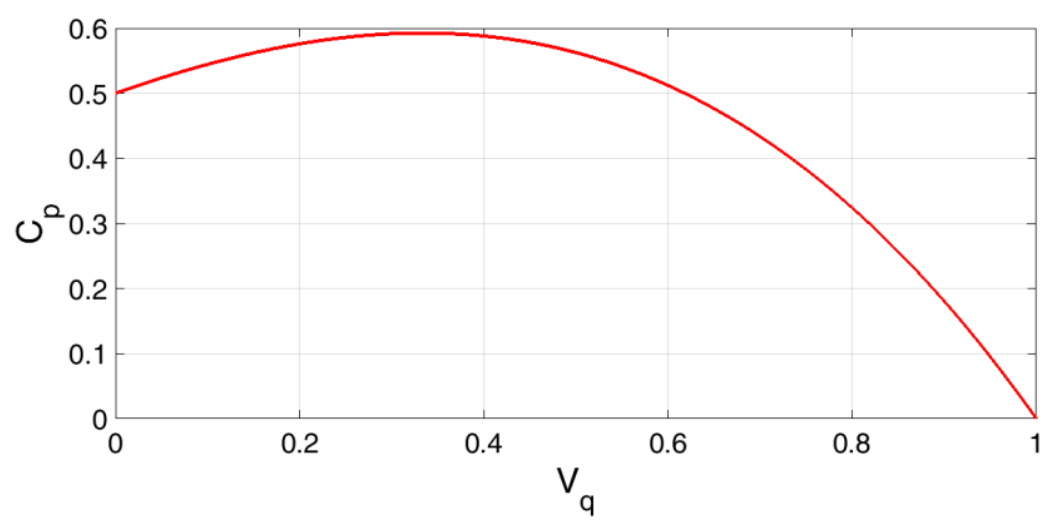

Fig. 2. Power coefficient as function of $V_{q}$.

\section{B. Representations of $\mathrm{Cp}$}

In actual wind systems, the left section of $\mathrm{Cp}$ is different to that shown in Fig. 2. In practice, the limit of $\mathrm{Cp}$ when $\mathrm{Vq}$ tends to zero is zero because, in that case, $\mathrm{V}_{1}$ is zero, therefore, there is no wind power to be extracted. Throughout the years, research has focused on obtaining functions that better represent the real graph of $\mathrm{Cp}$; some of them are the sinusoidal, exponential and algebraic representations [17].

1) Exponential models: They have been very commonly used in the literature [18-39], all of them adjusted to the general structure given by expression (4).

$$
C_{p}(\lambda, \beta)=C_{0}+\left(C_{1} \gamma-C_{2} \beta-C_{3} \beta^{C 4}-C_{5}\right) e^{-C 6 \gamma}+C_{7} \lambda
$$

Where $\lambda$ represents the tip speed ratio, $\beta$ is the pitch angle, and $\gamma$ is defined by equation (5).

$$
\gamma=\frac{1}{\lambda+d_{0} \beta+d_{1}}-\frac{d_{2}}{1+\beta^{3}}(5)
$$

Different values of coefficients are used depending on the authors (Table 1). Naturally, the complexity of the calculations, as well as the differences between the curves of $\mathrm{Cp}$, are related to the number of coefficients considered in the function defined for $\mathrm{Cp}$. The negative behavior of curves shown in Fig. 3 were suppressed by programming code.

Table 1. Coefficients of exponential model used by cited authors.

\begin{tabular}{|c|c|c|c|c|c|c|c|c|c|c|c|}
\hline Ref. & $\mathbf{C}_{0}$ & $\mathbf{C}_{1}$ & $\mathbf{C}_{2}$ & $\mathbf{C}_{3}$ & $\mathbf{C}_{4}$ & $\mathbf{C}_{5}$ & $\mathbf{C}_{6}$ & $\mathbf{C}_{7}$ & $\mathbf{d}_{0}$ & $\mathbf{d}_{1}$ & $\mathbf{d}_{2}$ \\
\hline$[18]$ & 1 & 110 & 0.4 & 0.002 & 2.2 & 9.6 & 18.4 & 0 & 0.02 & 0 & 0.03 \\
\hline
\end{tabular}




\begin{tabular}{|c|c|c|c|c|c|c|c|c|c|c|c|}
\hline Ref. & $\mathbf{C}_{\mathbf{0}}$ & $\mathbf{C}_{1}$ & $\mathbf{C}_{2}$ & $\mathbf{C}_{3}$ & $\mathbf{C}_{4}$ & $\mathbf{C}_{5}$ & $\mathbf{C}_{6}$ & $\mathbf{C}_{\mathbf{7}}$ & $\mathbf{d}_{\mathbf{0}}$ & $\mathbf{d}_{\mathbf{1}}$ & $\mathbf{d}_{\mathbf{2}}$ \\
\hline$[19]$ & 0.44 & 125 & 0.4 & 0 & 0 & 6.94 & 17.05 & 0 & 0.08 & 0 & 0.001 \\
\hline$[20-21]$ & 0.73 & 151 & 0.58 & 0.002 & 2.14 & 13.2 & 18.14 & 0 & 0.02 & 0 & 0.003 \\
\hline$[22]$ & 0.5 & 72.5 & 0.4 & 0 & 0 & 5 & 13.13 & 0 & 0.08 & 0 & 0.035 \\
\hline$[23-28]$ & 0.22 & 116 & 0.4 & 0 & 0 & 5 & 12.5 & 0 & 0.08 & 0 & 0.035 \\
\hline$[29-37]$ & 0.5176 & 116 & 0.4 & 0 & 0 & 5 & 21 & 0.0068 & 0.08 & 0 & 0.035 \\
\hline$[38]$ & 0.5 & 116 & 0.4 & 0 & 0 & 5 & 21 & 0 & 0 & 0.088 & 0.035 \\
\hline$[39]$ & 0.5 & 116 & 0.4 & 0 & 0 & 5 & 21 & 0 & 0.08 & 0 & 0.035 \\
\hline
\end{tabular}

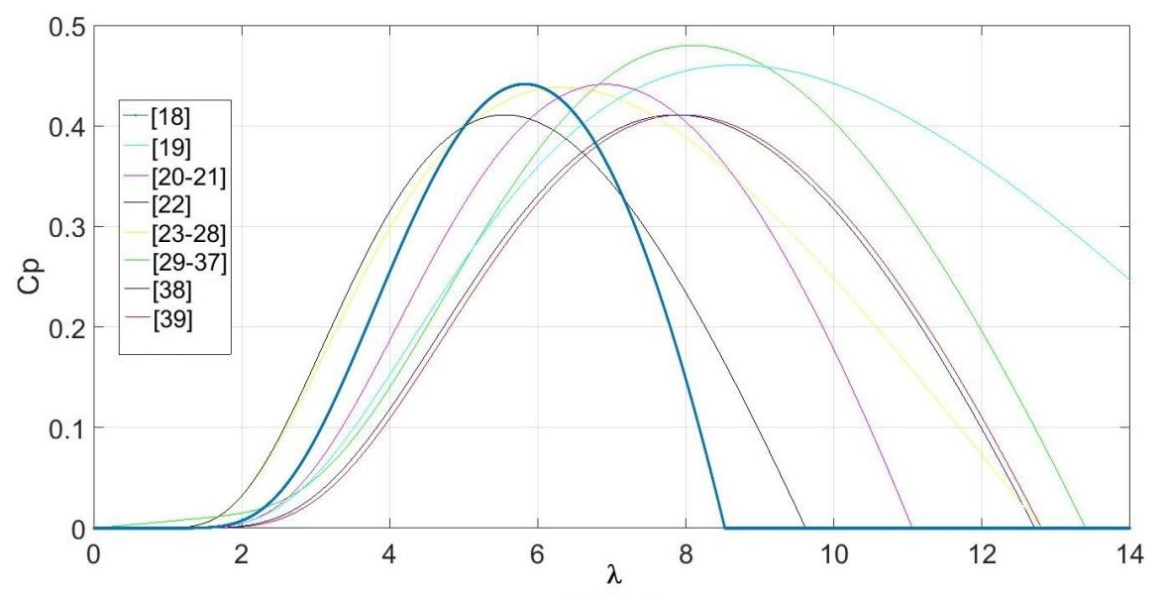

Fig. 3. Curves for exponential model of $\mathrm{Cp}$.

2) Sinusoidal model: Several authors have proposed a model for $\mathrm{Cp}$ using sinusoidal functions, so the curves are partially similar to the shape of Cp [40-43]. The general model is shown by expression (6).

$$
C_{p}(\lambda, \beta)=\left[a_{0}+a_{1}\left(b_{0} \beta+a_{2}\right)\right] \sin \left[\frac{\pi\left(\lambda+a_{3}\right)}{a_{4}+a_{5}\left(b_{1} \beta+a_{6}\right)}\right]+a_{7}\left(\lambda+a_{8}\right)\left(b_{2} \beta+a_{9}\right)
$$

Different values for coefficients $a_{i}$ and $b_{i}$ have been proposed (Table 2).

Table 2. Different sinusoidal coefficients proposed by authors.

\begin{tabular}{|c|c|c|c|c|c|c|c|c|c|c|c|c|c|}
\hline Ref. & $\mathbf{a}_{\mathbf{0}}$ & $\mathbf{a}_{\mathbf{1}}$ & $\mathbf{a}_{\mathbf{2}}$ & $\mathbf{a}_{\mathbf{3}}$ & $\mathbf{a}_{\mathbf{4}}$ & $\mathbf{a}_{\mathbf{5}}$ & $\mathbf{a}_{\mathbf{6}}$ & $\mathbf{a}_{\mathbf{7}}$ & $\mathbf{a}_{\mathbf{8}}$ & $\mathbf{a}_{9}$ & $\mathbf{b}_{\mathbf{0}}$ & $\mathbf{b}_{\mathbf{1}}$ & $\mathbf{b}_{\mathbf{2}}$ \\
\hline$[40]$ & 0.5 & 0.0167 & -2 & 0.1 & 18.5 & -0.3 & -2 & $-1.8 \mathrm{e}-3$ & -3 & -2 & 1 & 1 & 1 \\
\hline$[41]$ & 0.5 & -0.0167 & -2 & 0.1 & 10 & -0.3 & 0 & $-1.8 \mathrm{e}-3$ & -3 & -2 & 1 & 1 & 1 \\
\hline$[42]$ & 0.44 & -0.0167 & 0 & -3 & 15 & 0 & 0 & 0 & 0 & 0 & 0 & 0 & 0 \\
\hline$[43]$ & 0.5 & -0.0167 & -2 & 0.1 & 18.5 & -0.3 & -2 & $-1.8 \mathrm{e}-3$ & -3 & -2 & 1 & 1 & 1 \\
\hline
\end{tabular}

Fig. 4 shows the Cp curves for every proposed coefficient. Negative values of $\mathrm{Cp}$ are suppressed by programming code. The differences among the Cp curves mostly depend on the angle of the function sine. 


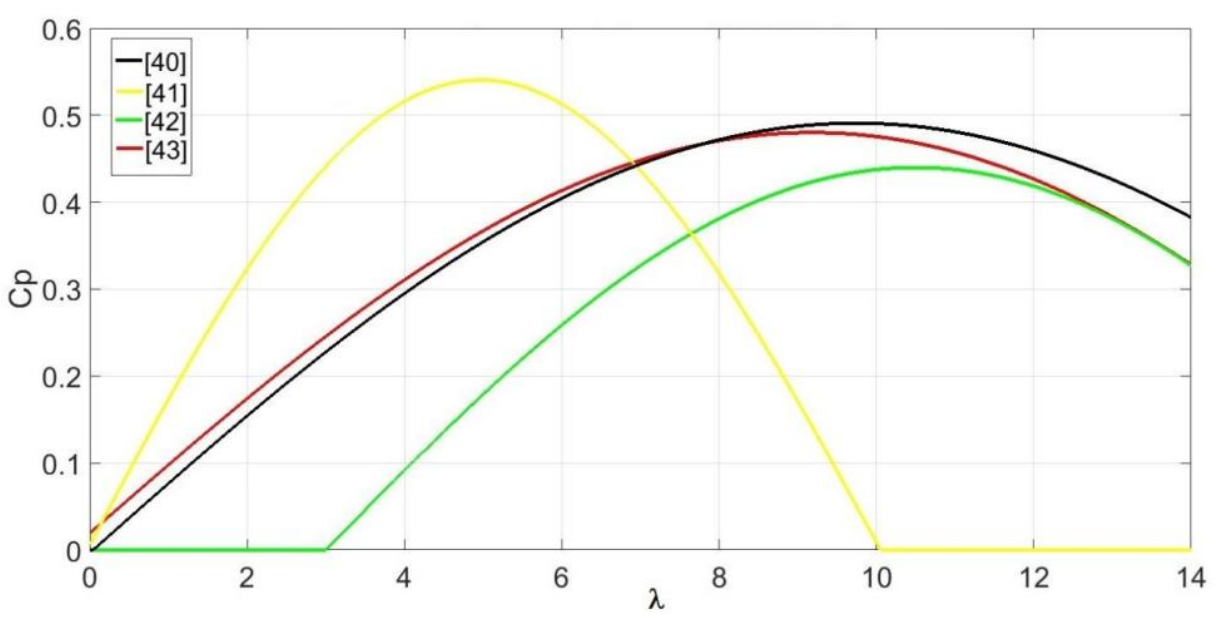

Fig. 4. Curves for sinusoidal model of $\mathrm{Cp}$.

3) Polynomial model: This is a very well-known model for representing $\mathrm{Cp}$, which curve is generated by equation (7). Nevertheless, eventually, this curve tends to either positive or negative infinity. The complexity of the calculations is naturally related to the number of coefficients used in the model. Four polynomials cases have been proposed by different authors, as well as a particular case that was developed in this paper [43-46]. Table 3 shows the proposed coefficients, and Fig 5. the curves.

$$
C_{p}(\lambda)=\sum_{i=0}^{n} a_{i} \lambda^{i}(7)
$$

Table 3. Proposed coefficients of polynomial model.

\begin{tabular}{|c|c|c|c|c|c|c|c|c|}
\hline Ref. & $\mathbf{a}_{\mathbf{0}}$ & $\mathbf{a}_{\mathbf{1}}$ & $\mathbf{a}_{\mathbf{2}}$ & $\mathbf{a}_{\mathbf{3}}$ & $\mathbf{a}_{4}$ & $\mathbf{a}_{\mathbf{5}}$ & $\mathbf{a}_{\mathbf{6}}$ & $\mathbf{a}_{\mathbf{7}}$ \\
\hline$[43]$ & -0.0209 & 0.1063 & -0.0048 & $-3.7 \mathrm{e}-5$ & 0 & 0 & 0 & 0 \\
\hline$[44]$ & 0 & 0.0051 & -0.0022 & 0.0052 & $-5.14 \mathrm{e}-4$ & $-2.79 \mathrm{e}-5$ & $4.63 \mathrm{e}-6$ & $-1.33 \mathrm{e}-7$ \\
\hline$[45]$ & 0.0344 & -0.0864 & 0.1168 & -0.0484 & 0.00832 & -0.0005 & 0 & 0 \\
\hline$[46]$ & 0.11 & -0.2 & 0.097 & -0.012 & 0.00044 & 0 & 0 & 0 \\
\hline Proposed & 0.01 & -0.0328 & 0.04926 & -0.0067 & $2.39 \mathrm{e}-3$ & 0 & 0 & 0 \\
\hline
\end{tabular}

Different curves generated by (7) accordingly to the proposed coefficients shown in Table 3 are illustrated in Fig. 5. Negative values of the curves proposed in [45, 46] were suppressed by programming code.

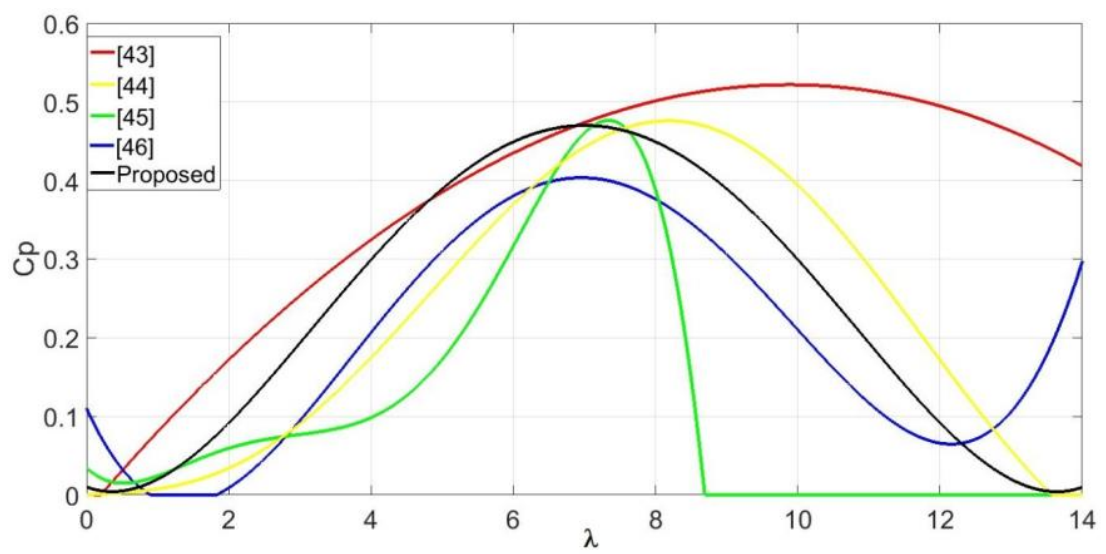

Fig. 5. Curves for polynomial model of $\mathrm{Cp}$. 
Noteworthy, the function proposed in this paper is perfectly adjusted along typical values of $\lambda$, it fits the practical limits of $\mathrm{Cp}$ when $\lambda$ tends to zero and is into the Betz limit. Coefficients were obtained through mathematical analysis by linear regression using MATLAB. Differences among the curves of $\mathrm{Cp}$ depend on the power of the polynomial and the coefficients associated to the terms.

\section{Estimators of $\mathrm{Cp}$}

Several studies have concentrated on estimating the curve of $\mathrm{Cp}$ through state observers [47-60]. Certainly, wind turbine manufacturers usually provide a $\mathrm{Cp}$ curve, but it eventually changes due to mechanical stress, friction or system robustness. The change in $\mathrm{Cp}$ causes undesirable results and difficulty in controlling the system appropriately [61-63].

1) Continuous state observer: Some researchers have proposed dynamic models to estimate $\mathrm{Cp}$. In [50], a continuous state observer is proposed to estimate $\mathrm{Cp}$ in a wind turbine connected to a separately excited dc generator to facilitate maximum power point tracking control design as shown in (8).

$$
\frac{d \widehat{\omega}}{d t}=\frac{\hat{C}_{p} \rho \pi R^{2} u^{3}}{2 J \omega}-\frac{\gamma K_{1} \hat{\imath}_{a}}{J}-\frac{B \omega}{J}+\frac{\rho \pi R^{2} u^{3}}{2 J \omega} \theta l_{1}(\omega-\widehat{\omega})(8)
$$

Where $\omega$ is angular speed, $C_{p}$ power coefficient, $\rho$ air density, $R$ rotor radius, $u$ wind speed, $J$ inertia, $V$ transmission gear ratio, $K_{1}$ induced emf constant, $i_{f}$ field current, $i_{a}$ armature current, $B$ turbine frictional constant, $\theta$ angular position, $l_{1}, l_{2}$ observer constants, $R_{T}$ armature + load resistance and $L_{T}$ armature + load inductance. Two advantages of this observer is that it is capable of handling measurement noise, and it can also have been applied to other WECS where different kinds of generators are used.

2) Alternative models: Some original models [64] have also been proposed to represent the Cp curve such as expressions (9) and (10).

$$
\begin{aligned}
& \operatorname{Cp}(\lambda)=\frac{1}{0.95 \sqrt{2 \pi}} e^{-\left(\frac{0.1296}{1.805} \lambda^{2}-\frac{2.0736}{1.805} \lambda+\frac{8.2944}{1.805}\right)} \\
& \operatorname{Cp}(\lambda)=\frac{1.8 e^{-0.18(\lambda-4)}}{\left(1+e^{-0.18(\lambda-4)^{2}}\right)\left(1+e^{-1.26(\lambda-4)}\right)}
\end{aligned}
$$

On one hand, Figure 6 shows the associated curve to expression (9), which has the advantage of having a limited magnitude of $\mathrm{Cp}$, even for values of $\lambda$ that are outside of the experimentally feasible limits. This expression is similar than that used as a stochastic function. On the other hand, it can be observed in Figure 7 the related curve to expression (10) which has a bias factor that allows a better approximation to the real $\mathrm{Cp}$ curve. 


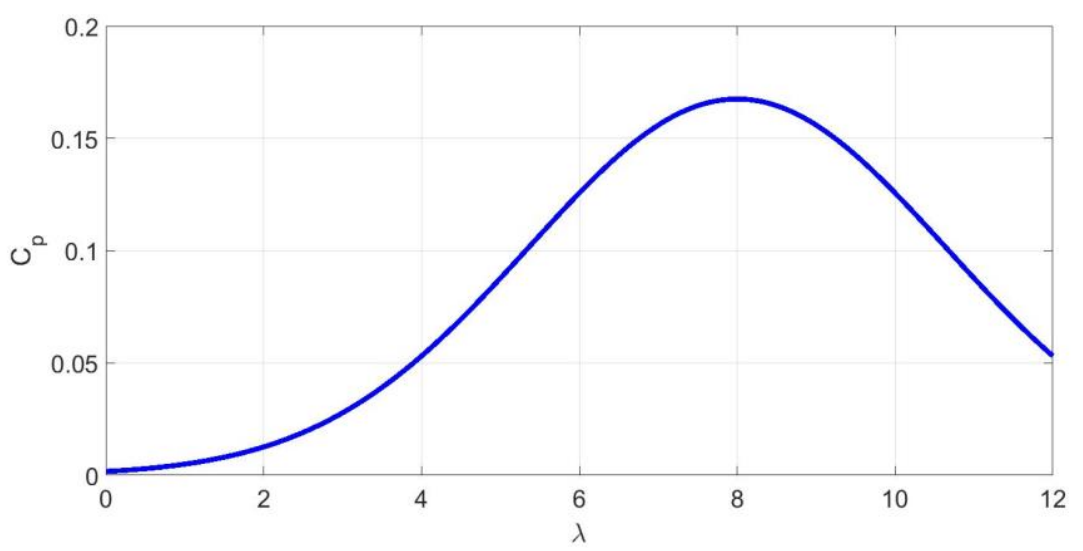

Fig. 6. Curve for first alternative model of $\mathrm{Cp}$.

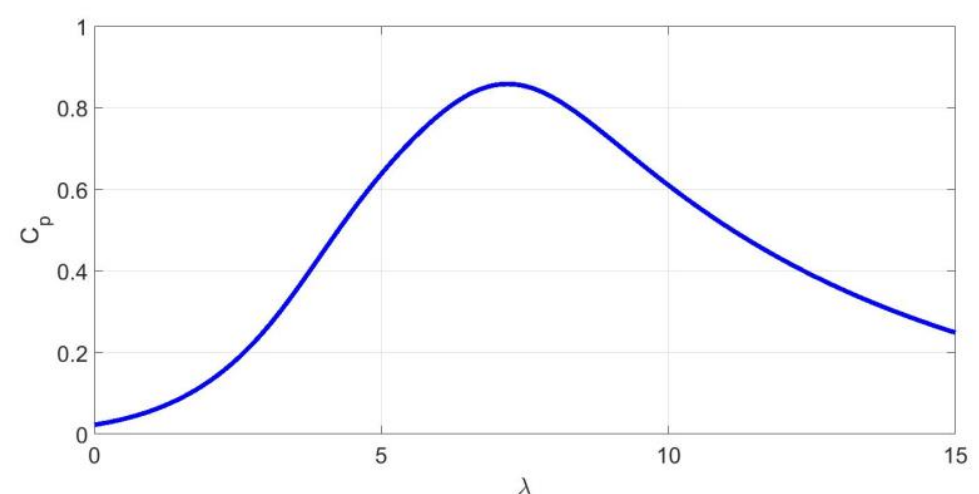

Fig. 7. Curve for second alternative model of $\mathrm{Cp}$.

\section{Results and discussion}

After reviewing the literature about representations and estimation of $\mathrm{Cp}$, we found an important variety of models, whose advantages and disadvantages are summarized in Table 4 . In the case of the representation of $\mathrm{Cp}$ by a polynomial of 4th grade, the results were obtained using the mathematical software MATLAB, establishing the equations to solve different coefficients of this polynomial by considering a symmetrical response of $\mathrm{Cp}$. Several approximations were made before obtaining the most suitable coefficients for the 4th grade polynomial, keeping the values of $\mathrm{Cp}$ under Betz coefficient.

Moreover, we obtained alternative models through heuristic tests based on the stochastic function of probability. We obtained good results in values of $\mathrm{Cp}$ even in the regions beyond the operation zone of tip speed ratio, so this is the relevance of this representation for $\mathrm{Cp}$. As there are few studies about representations and estimations of $\mathrm{Cp}$, one of the relevancies of this work is to show these models after doing an exhaustive bibliographical research, which constitutes the main strength of this work.

Table 4. Summary of representations and estimators for $\mathrm{Cp}$.

\begin{tabular}{|c|l|l|l|}
\hline & \multicolumn{2}{|c|}{ Advantages } & \multicolumn{1}{c|}{ Disadvantages } \\
\hline $\begin{array}{c}\text { Exponential } \\
\text { model }\end{array}$ & $\begin{array}{l}\text { Only two equations should be } \\
\text { handled. It is relatively easy to } \\
\text { implement. Using the correct } \\
\text { coefficients, the results are reliable }\end{array}$ & $\begin{array}{l}\mathrm{Cp} \text { curve eventually grows } \\
\text { disproportionately to either plus or } \\
\text { minus infinity }\end{array}$ \\
\hline
\end{tabular}




\begin{tabular}{|c|c|c|}
\hline & Advantages & Disadvantages \\
\hline & $\begin{array}{l}\text { within a practical range of values of } \\
\text { tip speed ratio }\end{array}$ & \\
\hline $\begin{array}{l}\text { Sinusoidal } \\
\text { model }\end{array}$ & $\begin{array}{l}\text { Only one equation should be } \\
\text { handled. By choosing appropriately } \\
\text { the coefficients of the equation, } \\
\text { reliable results are obtained }\end{array}$ & $\begin{array}{l}\text { Oscillatory behavior might be } \\
\text { presented out of the practical range } \\
\text { of tip speed radio }\end{array}$ \\
\hline $\begin{array}{l}\text { Polynomial } \\
\text { model }\end{array}$ & $\begin{array}{l}\text { The model is very simple and easy to } \\
\text { implement. It is always possible to } \\
\text { adjust a curve for a certain number of } \\
\text { given points, nevertheless the higher } \\
\text { grade of the polynomial, the more } \\
\text { complexity of the calculations and } \\
\text { processing time. }\end{array}$ & $\begin{array}{l}\text { The number of concavities of } \mathrm{Cp} \\
\text { curve increases proportionally to the } \\
\text { grade of the polynomial model }\end{array}$ \\
\hline $\begin{array}{l}\text { Continuous } \\
\text { observer }\end{array}$ & $\begin{array}{l}\text { It is capable of handling } \\
\text { measurement noise and it could be } \\
\text { applied to other WECS where } \\
\text { different kinds of generators are } \\
\text { used }\end{array}$ & $\begin{array}{l}\text { Reliability of observer depends on } \\
\text { measures of } \mathrm{i}_{\mathrm{f}}, \omega \text { and } V_{a} \text { and high } \\
\text { speed data processing. Experimental } \\
\text { implementation is recommended }\end{array}$ \\
\hline $\begin{array}{l}\text { Alternative } \\
\text { models }\end{array}$ & $\begin{array}{l}\text { They present a limited magnitude of } \\
\text { Cp even for values of } \lambda \text { that are } \\
\text { outside of the experimentally } \\
\text { feasible limits. }\end{array}$ & $\begin{array}{l}\text { A rigorous method for the proposal of } \\
\text { the alternative models was not } \\
\text { followed, so they are susceptible to } \\
\text { improve. }\end{array}$ \\
\hline
\end{tabular}

\section{Conclusion}

Based on the available literature, several models have been proposed to describe $\mathrm{Cp}$, but they are only approximations and usually present problems representing $\mathrm{Cp}$ for values out of the typical zone of tip speed radio, especially exponential, sinusoidal and polynomial models. For estimating $\mathrm{Cp}$ by state observers, curves of $\mathrm{Cp}$ are more accurate, but they imply a considerable increase in complexity and calculations. All these models present values of $\mathrm{Cp}$ lower than the Betz limit of 0.593 .

An analysis of the behavior of alternative models showed that they presented an accurate approximation to the real $\mathrm{Cp}$ curve for values of tip speed ratio above the typical zone; they may be an important alternative for representing $\mathrm{Cp}$, however, the first one presents a maximum value of just 0.17 for $\mathrm{Cp}$, while the second is above the Betz limit.

After reviewing the state of the art, we found only few studies about power coefficient estimation, so it still constitutes an important field worthy to be studied. It may be a trend topic in the near future.

\section{Author's contribution}

J. G. González Hernández: reviewing of the state of the art, analysis of information, experimental tests, programming, generation of tables and graphics. R. Salas Cabrera: supervisor of the research, reviewer of structure and syntax, critical analysis of the information and approval of results.

\section{References}

[1] F. Manzano-Agugliaro, A. Alcayde, F. G. Montoya, A. Zapata-Sierra, and C. Gil, "Scientific production of renewable energies worldwide: An overview," Renewable and Sustainable Energy Reviews, vol. 18, pp. 134-143, Feb. 2013. DOI: https://doi.org/10.1016/j.rser.2012.10.020. 
[2] H. H. Chen, and A. H. I. Lee, "Comprehensive overview of renewable energy development in Taiwan," Renewable and Sustainable Energy Reviews, vol. 37, pp. 215-228, Sep. 2014. DOI: https://doi.org/10.1016/j.rser.2014.04.055.

[3] L. Tripathi, A. K. Mishra, A. Kumar-Dubey, C. B. Tripathi, and P. Baredar, "Renewable energy: An overview on its contribution in current energy scenario of India," Renewable and Sustainable Energy Reviews, vol. 60, pp. 226-233, Jul. 2016. DOI: https://doi.org/10.1016/j.rser.2016.01.047.

[4] S. Yong-Duan, L. Peng, U. Wei, and Q. Ming, "An overview of renewable wind energy conversion system modeling and control," Measurament and Control, vol. 43 (7), pp. 203-208, 2010. DOI: https://doi.org/10.1177/002029401004300703.

[5] A. K. Hussein, "Applications of nanotechnology in renewable energies-A comprehensive overview and understanding," Renewable and Sustainable Energy Reviews, vol. 42, pp. 460-476, Feb. 2015. DOI: https://doi.org/10.1016/i.rser.2014.10.027.

[6] R. Bedard, P. T. Jacobson, M. Previsic, W. Musial, and R. Varley, "An Overview of Ocean Renewable Energy Technologies," Oceanography, vol. 23 (2), pp. 22-31, 2010. DOI: https://doi.org/10.5670/oceanog.2010.40.

[7] M. Dyrholm, S. Sawyer, L. Fried, C. Gill, I. Prosser, S. Shukla, L. Quiao, and L. Livzeniece, "Global Wind Energy Council Report," GWEC, Abr 2018. Available: http://gwec.net/publications/global-wind-report-2/.

[8] R. Vennell, "Exceeding the Betz limit with tidal turbines", Renewable Energy, vol. 55, pp. 277-285, Jul. 2013. DOI: https://doi.org/10.1016/i.renene.2012.12.016.

[9] S. P. Farthing, "Technical note: Betz limit, not an exact optimum," Wind Engineering, vol. 37 (1), pp. 105-110, Feb. 2013. DOI: https://doi.org/10.1260/0309-524X.37.1.105.

[10] S. Zekai, "Modified wind power formulation and its comparison with Betz limits," International Journal of Energy Research, vol. 37 (8), pp. 959-963, Jun. 2013. DOI: https://doi.org/10.1002/er.2900.

[11] R.M. Ochieng, and R.O. Ochieng, "A power series formulation of the Betz's criterion and equation in a wind turbine," International Journal of Energy, Environment and Economics, vol. 23 (2), pp. 291-299, 2015.

[12] V. L. Okulov, and J. N. Sørensen, "Refined Betz limit for rotors with a finite number of blades," Wind Energy, vol. 11 (4), pp. 415-426, 2008. DOI: https://doi.org/10.1002/we.274.

[13] Y. Venkata, W. Bin, C. S. Paresh, K. Samir, and M. Mehdi, "High Power Wind Energy Conversion Systems: State-ofthe-Art and Emerging Technologies," Proc. of IEEE, vol. 103 (5), pp. 740-778, May. 2015. DOI: https://doi.org/10.1109/JPROC.2014.2378692.

[14] R. Mittal, K. S. Sandhu, and D. K. Jain, "An Overview of Some Important Issues Related to Wind Energy Conversion Systems (WECS)," International Journal of Environmental Science and Development, vol. 1 (4), pp. 351-363, Oct. 2010. DOI: https://doi.org/10.7763/IJESD.2010.V1.69.

[15] E. C. Millán, El sistema eólico, diseño aerodinámico. Madrid, ESP: Ed. EOI, 2007.

[16] F. D. Bianchi, H. de-Batista, and R. J. Mantz, Wind Turbine Control Systems Principles, Modeling and Gain Scheduling Design, Chapter 2, Luxemburgo, LUX: Springer, 2007.

[17] V. Reyes, J. J. Rodríguez, O. Carranza, and R. Ortega, "Review of mathematical of both the power coefficient and the torque coefficient in wind turbines," in IEEE 24th International Symposium on Industrial Electronics, Río de Janeiro, Brazil, 2015, pp. 1458-1463. DOI: https://doi.org/10.1109/ISIE.2015.7281688.

[18] A. Ahmad, D. Ahmed, and F. Karim, "Design and modeling of lowspeed axial flux permanent magnet generator for wind based microgeneration systems," in International Conference on Robotics and Emerging Allied Technologies in Engineering (iCREATE), Islamabad, Pakistan, 2014, pp. 51-57.

[19] G. Bustos, F. Milla, D. Saez, L. S. Vargas, H. Zareipour, and A. Nuñez, "Comparison of fixed speed wind turbines models: a case study," in 38th Annual Conference on IEEE (IECON), Montreal, QC, 2012, pp. 961-966. DOI: https://doi.org/10.1109//ECON.2012.6388937.

[20] G. Boukettaya, O. Naifar, and A. Ouali, "A vector control of a cascaded doubly fed induction generator for a wind energy conversion system," in 11th International Multi-Conference on Systems, Signals \& Devices (SSD), Barcelona, Spain, 2014, pp. 1-7.

[21] X. Cai, G. Shi, Z. Wang, L. Yao, and M. Zhu, "Generalized average model of DC wind turbine with consideration of electromechanical transients," in IECON 2013 - 39th Annual Conference of the IEEE, Vienna, 2013, pp. 1638-1643.

[22] D. Llano, R. McMahon, and M. Tatlow, "Control algorithms for permanent magnet generators evaluated on a wind turbine emulator test-ring," in 7th IET International Conference on Power Electronics, Machines and Drives (PEMD), Mancester, UK, 2014, pp. 1-7. DOI: https://doi.org/10.1049/cp.2014.0304.

[23] J. Chen, and D. Jiang, "Study on modeling and simulation of non-grid-connected wind turbine," in WNWEC 2009 World Non-Grid-Connected Wind Power and Energy Conference, Nanjing, China, 2009, pp. 1-5. DOI: https://doi.org/10.1109/WNWEC.2009.5335791.

[24] J. Chen, H. Wu, M. Sun, and W. Jiang, "Modeling and simulation of directly driven wind turbine with permanent magnet synchronous generator," in IEEE Innovative Smart Grid Technologies - Asia (ISGT Asia), Tianjin, China, 2012, pp. 1-5.

[25] Q. Shi, G. Wang, L. Fu, L. Yuan, and H. Huang, "State-space averaging model of wind turbine with PMSG and its virtual inertia control," in IECON 2013 - 39th Annual Conference of the IEEE Industrial Electronics Society, Vienna, Austria, 2013, pp. 1880-1886. DOI: https://doi.org/10.1109/IECON.2013.6699418.

[26] Y. Ming, L. Gengyin, M. Zhou, and C. Zhao, "Modeling of the wind turbine with a permanent magnet synchronous generator for integration," in IEEE Power Engineering Society General Meeting, Tampa, FL, 2007, pp. 1-6.

[27] S. K. Bagh, P. Samuel, R. Sharma, and S. Banerjee, "Emulation of static and dynamic characteristics of a wind turbine using Matlab/Simulink," in 2nd International Conference on Power, Control and Embedded Systems (ICPCES), Allahabad, India, 2012, pp. 1-6. DOI: https://doi.org/10.1109/ICPCES.2012.6508105.

[28] F. Gao, D. Xu, and Y. Lv, "Hybrid automaton modeling and global control of wind turbine generator," in Proceedings of Seventh International Conference on Machine Learning and Cybernetics, Kunming, China, 2008, pp. 1991-1997.

[29] Y. Guo, S. H. Hosseini, C. Y. Tang, and J. N. Jiang, "An approximate model of wind turbine control systems for wind farm power control," in 2011 IEEE Power and Energy Society, San Diego, CA, 2011, pp. 1-7. DOI: https://doi.org/10.1109/PES.2011.6038985.

[30] B. Hamane, M. L. Doumbia, M. Bouhamida, and M. Benghanem, "Control of wind turbine based on DFIG using Fuzzy$\mathrm{PI}$ and sliding mode controllers," in Ninth International Conference on Ecological Vehicles and Renewable Energies (EVER), Monte-Carlo, Monaco, 2014, pp. 1-8. DOI: https://doi.org/10.1109/EVER.2014.6844060.

[31] Y. Guo, S. H. Hosseini, J. N. Jiang, C. Y. Tang, and R.G. Ramakumar, "Voltage/Pitch control for maximization and regulation of active/reactive powers in wind turbines with uncertainties," in 49th IEEE Conference on Decision and Control (CDC), Atlanta, GA, 2010, pp. 3956-3963. DOI: https://doi.org/10.1109/CDC.2010.5716987.

Revista Facultad de Ingeniería (Rev. Fac. Ing.) Vol. 28 (50), pp. 77-90. Enero-Marzo, 2019. Tunja-Boyacá, Colombia. L-ISSN: 0121-1129, e-ISSN: 2357-5328, DOI: https://doi.org/10.19053/01211129.v28.n50.2019.8816 
[32] A. B. Cultura, and Z. M. Salameh, "Modeling and simulation of a wind turbine-generator system," in IEEE Power and Energy Society General Meeting, San Diego, CA, 2011, pp. 1-7. DOI: https://doi.org/10.1109/PES.2011.6039668.

[33] S. Duman, I. H. Altas, N. Yorukeren, and A. M. Sharaf, "A novel FACTS based on modulated power filter compensator for wind-grid energy systems," in IEEE 5th International Symposium on Power Electronics for Distributed Generation Systems (PEDG), Galway, Ireland, 2014, pp. 1-7. DOI: https://doi.org/10.1109/PEDG.2014.6878656.

[34] P. Aree, and S. Lhaksup, "Dynamic simulation of self-excited Induction Generator feeding motor load using matlab/Simulink," in 11th International Conference on Electrical Engineering/Electronics, Computer, Telecommunications and Information Technology (ECTICON), Nakhon Ratchasima, Tailand, 2014, pp. 1-6. DOI: https://doi.org/10.1109/ECTICon.2014.6839863.

[35] Z. Jin, and X. Ma, "Semi-definite programming for power output control in a wind energy conversion system," IEEE Transactions on sustainable energy, vol. 5 (2), pp. 466-475, Jan. 2014. DOI: https://doi.org/10.1109/TSTE.2013.2293551. [36] R. Cao, L. Lu, Z. Xie, X. Zhang, and S. Yang, "A dynamic wind turbine simulator of the wind turbine generator system," in International Conference on Intelligent System design and engineering application, Kuala Lumpur, Malaysia, 2012, pp. 967-970.

[37] R. II. Ovando, J. Aguayo, and M. Cotorogea, "Emulation of a low power wind turbine with a DC motor in Matlab/Simulink," in Power Electronics Specialists Conference, 2007, pp. 859-864.

[38] S. Khajuria, and J. Kaur, "Implementation of pitch control of wind turbine using Simulink (Matlab)," International Journal of Advanced Research in Computer Engineering \& Technology, vol. 1 (4), pp. 196-200, 2012.

[39] S. Janakiraman, R. Kotti, and W. Shireen, "Adaptive sensorless maximum power point tracking control for PMSG wind energy conversion systems," in Workshop on Control and modeling for Power Electronics (COMPEL), Santander, Spain, 2014, pp. 1-8.

[40] I. Nouira, and A. Khedher, "A contribution to the design and the installation of an universal platform of a wind emulator using a DC motor," International Journal of renewable energy research, vol. 2 (4), pp. 797-804, 2012.

[41] E. Madjid, S. Mekhilef, and F. Merahi, "DC-Voltage regulation of a five levels neutral point clamped cascaded for wind energy conversion system," in The 2014 International Power Electronics Conference, Hiroshima, Japan, 2014, pp. 560566.

[42] Q. Bin, L. Pengcheng, Z. Wanli, and W. Xin, "Sliding mode control of pitch angle for direct driven PM wind turbine," in 26th Chinese Control and Decision Conference (CCDC), Changsha, China, 2014, pp. 2447-2452. DOI: https://doi.org/10.1109/CCDC.2014.6853039.

[43] I. Moussa, A. Bouallegue, and A. Kehedher, "Design and Implementation of constant wind speed turbine emulator using Matlab/simulink and FPGA," in Ninth International Conference Ecological Vehicles and Renewable Energies (EVER), Monaco, 2014, pp. 1-8. DOI: https://doi.org/10.1109/EVER.2014.6844051.

[44] W. Li, H. Ma, D. Xu, and W. Zhang, "Research on Wind Turbine Emulation based on DC Motor," in Second IEEE conference on industrial electronics and applications, Harbin, China, 2007, pp. 2589-2593. DOI: https://doi.org/10.1109/ICIEA.2007.4318881.

[45] O. Carranza, E. Miranda, R. Ortega, and J. J. Rodríguez, "Emulador de un aerogenerador de baja potencia utilizando un Generador Síncrono de Imán Permanente," in Reunión de Verano de Potencia y aplicaciones industriales, Acapulco México, 2014.

[46] M. D. Arifujjaman, M. T. Iqbal, and J. E. Quaicoe, "Maximum power extraction from a small wind turbine emulator using a DC-DC converter controlled by a microcontroller," in 4th International Conference on Electrical and Computer Engineering ICECE, Dhaka, Bangladesh, 2006, pp. 213-216. DOI: https://doi.org/10.1109/ICECE.2006.355328.

[47] M. L. Corradini, G. Ippoliti, and G. Orlando, "A robust observer for detection and estimation of icing in wind turbines," in IECON 2016 - 42nd Annual Conference of the IEEE Industrial Electronics Society, Florence, Italy, 2016, pp. 1894-1899. DOI: https://doi.org/10.1109/IECON.2016.7793039.

[48] C. Caruana, A. Al-Durra, and F. Blaabjerg, "Observer-based scheme for tuning the control of variable speed wind turbines operating in hostile environments," IET Renewable Power Generation, vol. 10 (3), pp. 418-425, Feb. 2016. DOI: https://doi.org/0.1049/iet-rpg.2015.0146.

[49] J. Sandoval-Moreno, G. Besançon, and J. J. Martinez, "Observer-based maximum power tracking in wind turbines with only generator speed measurement," in 2013 European Control Conference (ECC), Zurich, Switzerland, 2013, pp. 478-483. DOI: https://doi.org/10.23919/ECC.2013.6669847.

[50] B. Yap, L. Dodson, and K. Busawon, "Online estimation of the power coefficient in wind energy conversion systems," in 2012 2nd International Symposium on Environment Friendly Energies and Applications, Newcastle, UK, 2012, pp. 458463. DOI: https://doi.org/10.1109/EFEA.2012.6294038.

[51] A. J. Mahdi, W. H. Tang, and Q.H. Wu, "Estimation of tip speed ratio using an adaptive perturbation and observation method for wind turbine generator systems," in IET Conference on Renewable Power Generation (RPG 2011), Edinburgh, Scotland, 2011, pp. 1-6. DOI: https://doi.org/10.1049/cp.2011.0133.

[52] K. Busawon, M. Jovanovic, and L. Dodson, "Power Coefficient Estimation in a Wind Energy Conversion System," in 12th International Power Electronics and Motion Control Conference, Portoroz, Slovenia, 2006, pp. 1873-1877.

[53] K. Busawon, L. Dodson, and M. Jovanovic, "Estimation of the power coefficient in a wind conversion system," in Proceedings of the 44th IEEE Conference on Decision and Control, Seville, Spain, 2005, pp. 3450-3455. DOI: https://doi.org/10.1109/CDC.2005.1582696.

[54] R. Aubrée, F. Auger, and P. Dai, "A new low-cost sensorless MPPT algorithm for small wind turbines," in First International Conference on Renewable Energies and Vehicular Technology, Hammamet, Tunisa, 2012, pp. 305-311. DOI: https://doi.org/10.1109/REVET.2012.6195288.

[55] A. Monroy, and L. Alvarez-Icaza, "Real-time identification of wind turbine rotor power coefficient," in 45th Conference on Decision \& Control, San Diego, USA, 2006, pp. 3690-3695. DOI: https://doi.org/10.1109/CDC.2006.376895.

[56] G. T. Son, H. J. Lee, and J.W. Park, "Estimation of Wind Turbine Rotor Power Coefficient Using RMP Model," in Proc. Industry Applications Society Annual Meeting, Houston, USA, 2009, pp. 1-8 DOI: https://doi.org/10.1109/IAS.2009.5324837.

[57] P. F. Odgaard, R. Nielsen, and C. Damgaard, "On-line estimation of wind turbine power coefficients using unknown input observers," in IFAC Proceedings Volumes (IFAC-PapersOnline), 2008. DOI: https://doi.org/10.3182/20080706-5KR-1001.0149.

[58] A. B. Asghar, and X. Liu, "Estimation of wind turbine power coefficient by adaptive neuro-fuzzy methodology," Neurocomputing, vol. 238, pp. 227-233, May. 2017. DOI: https://doi.org/10.1016/i.neucom.2017.01.058.

[59] A. Monroy, and L. Alvarez-Icaza, "Wind turbine power coefficient real-time identification," International Journal of Modelling, Identification and Control, vol. 6 (3), pp. 181-187, 2009. DOI: https://doi.org/10.1504/IJMIC.2009.024457.

Revista Facultad de Ingeniería (Rev. Fac. Ing.) Vol. 28 (50), pp. 77-90. Enero-Marzo, 2019. Tunja-Boyacá, Colombia. L-ISSN: 0121-1129, e-ISSN: 2357-5328, DOI: https://doi.org/10.19053/01211129.v28.n50.2019.8816 
[60] G. Hafidi, and J. Chauvin, "Wind speed estimation for wind turbine control," in Proceedings of the IEEE international conference on control applications, Dubrovnik, Croatia, Oct. 2012, pp. 1111-1117. DOI: https://doi.org/10.1109/CCA.2012.6402654.

[61] H. Kala, and K. S. Sandhu, "Effect of change in power coefficient on the performance of wind turbines with different dimensions," in International Conference on Microelectronics, Computing and Communication, MicroCom, Durgapur, India, 2016, pp. 1-4. DOI: https://doi.org/10.1109/MicroCom.2016.7522487.

[62] R. S. Pukale, K. U. Jadhav, and A. G. Thosar, "Data collection of variable wind speed to study the change in power and power coefficient," in International Conference on Energy Efficient Technologies for Sustainability ICEETS, Nagercoil, India, 2013. DOI: https://doi.org/10.1109/ICEETS.2013.6533413.

[63] J. Dai, D. Liu, L. Wen, and X. Long, "Research on power coefficient of wind turbines based on SCADA data," Renewable Energy, vol. 86, pp. 206-215, Feb. 2016. DOI: https://doi.org/10.1016/i.renene.2015.08.023.

[64] I.M. De-la-Rosa-Alejandre, "Observador no lineal para la máquina de imanes permanentes," Master thesis, Madero Institute of Technology, Mexico, 2013.

[65] D. Jena, and S. Rajendran, "A review of estimation of effective wind speed based control of wind turbines," Renewable and Sustainable Energy Reviews, vol. 43, pp. 1046-1062. DOI: https://doi.org/10.1016/i.rser.2014.11.088. 